\title{
The Influence of Principal's Policy and Finance on the Quality of Education
}

\author{
Agustirini ${ }^{1 *}$, Bukman $\operatorname{Lian}^{2}$, Syaiful Eddy ${ }^{2}$ \\ ${ }^{1}$ SD Negeri 1 Lingkis \\ ${ }^{2}$ Universitas PGRI Palembang \\ *Corresponding Autor. Email: Rini8231@yahoo.co.id
}

\begin{abstract}
The study aims at analyzing and determining the effect of the principal's policy and education financing on the quality of Public Elementary School (SDN) in Jejawi District. The type of research is a descriptive quantitative. The samples were 100 respondents, and the data collection techniques in the form of a questionnaire. The results showed that: 1) there was a significant effect of the principal's policy on the quality of education;2) there was a significant effect of education financing on the quality of education; and 3) there was a significant influence between the principal's policy and education financing on the quality of education.
\end{abstract}

Keywords: Principal Policy, Education Financing, Education Quality

\section{INTRODUCTION}

The authority to administer education and the educational resource allocation through school based management system leads to the demand of decentralization and regional autonomy policies. It is based on the Regional Government Law Number 32 of 2004, and number 33 of 2004 [1] related to the Financial Considerations Central and Regional [2]. School Based Management (SBM) can be defined as a management model that provides schools with greater autonomy (authority and responsibility), flexibility, and encouragement centered on national education policy and regulations, for school participants (teachers, educators, principals, employees) and societies (parents of students, political officials, academics, developers, and so on) to increase the efficiency of schooling.

The principals have an important role for the school success. They perform the role as a leader including supervising staff, interacting with students, supervising work discipline with families and communities, managing school facilities, assisting with curriculum, planning for staff development, and managing budgets. By those responsibilities, it is not surprising that strong leadership of the principal contributes to the effective schools [3].

In line with this, it is argued that a professional school principal has a very fundamental positive impact on schools and becomes one of the new paradigm in education management [4]. This positive impact can be seen from the increasing of the quality in education, professional leadership, effective management of all components of education, organizational culture, solid team, intellegence, creativity, independence, active involvement in society, transparency in management, willingness towards changes both from psychological and physical aspects, and continuous evaluation with various improvements. A school principal is required to have a clear and directed vision and mission, as well as a comprehensive education management strategy and oriented towards good qulity of education. This strategy is an effort that is conceptualized in a systematic and coordinated ways to increase the level of education facilities. The strategy is directed to students, parents, alumni, educators, employees, government, and the community.

In the implementation of education, financing for elementary school in Jejawi sub-district is very decisive. Without cost, the educational activity in Jejawi sub-district will not run smoothly. Almost no educational efforts can ignore the role of costs so it can be said that without education financing, the educational process, especially in schools, will not work. Education financing is an analysis of the sources and uses of costs intended for efficient management of education in order to achieve educational goals. 
Educational financing for public elementary school in Jejawi district is supported by School Operational Suppport (BOS). Although the schools cannot fully use BOS funds, they are sufficient to help alleviate education fees that must be paid by students.

Based on previous research conducted by Damayani et al, the performance of school principals and teacher in the learning process in the school environment is a factor of achieving educational goals. The performance of school principals and teachers is the spearhead in the world of education. Either high or low quality of the principal and teacher performance results in the progress and the quality of schools [5].

School financial management is not only related to the management of fund sources used for the education process [6], but also various financial management problems. The school efforts to find sources of financing are used for the sustainability of the organization. Whereas, management refers to the process of coordinating and integrating work activities to be resolved efficiently and effectively by other members of people in the organization [7].

Furthermore, the principal as a leader of an educational institution has to understand thoroughly how to manage his managerial abilities in the institution. He or she has to be able to prepare the school to compete in the era of globalization and yet remain cultured. Educational institutions are a production that will propose quality human resources who will become the backbone of the implementation of national development. [8]

In general, the principal performance can be interpreted as the quality and quantity of work achieved by the principal in carrying out his function as a leader in accordance with the responsibilities given to him [9]. Accordingly, Mulyasa notes that the principal has to be able to increase school productivity. The productivity can be seen from the educational output in the form of an educational atmosphere. Achievements can be seen from equitable input, a large number of graduates, high quality of graduates, high relevance, and great amont of income. Meanwhile, the process or atmosphere can be seen in the enthusiasm of learning, high morale, and trust from various parties. With the improvement of the quality of education, it is hoped that graduates will be more capable of becoming educational staff who can carry out their duties well [10]

Furthermore, Mulyasa suggests that the leadership aspect of the principal is responsible for the implementation of effective teaching in school. The principal has to be able to carry out the duties and functions properly and professionally. The school principal has to understand, master and be able to carry out activities related to his function as a leader. As a manager, the principal is required to be able to realize the vision and mission and goals that have been set by utilizing all school resources. The school principal has to be able to overcome and innovate for numerous school challenges, thinks analytically and conceptually, and seeks to become a mediator in the resolution of various problems encountered by his subordinates in the education staff.

Given the importance of the education quality, the researchers conducted a study concerning with the Effect of Principal Policies and Education Financing on Education Quality at SDN Jejawi District.

\section{METHOD}

According to Sukmadinata, the research approach is a collection of techniques or practices for conducting research that are focused on fundamental concepts, metaphysical and ideological viewpoints, concerns, and problems. There is a particular test style for the research process.. This type of research is quantitative method by describing the research findings [11].

The quantitative research is based on the philosophy of positivism that emphasizes the objective phenomena and is studied quantitatively. The sample of this study was SDN in Jejawi District by using purposive sampling. The teachers taken as the respondents were teachers in each primary school with a total number of 100 . In collecting the data, techniques are needed both in providing and in classifying the data that have been collected. According to Sugiyono, the data collection method is a method used to collect the data, while the data collection technique is the method used in carrying out the method that has been chosen by using questionnaire data and documentation [12]. The data analysis technique in this study used is simple correlation and multiple regression data analysis techniques with the help of the SPSS For Windows Version 22. The analysis implementation stages included: 1). descriptive analysis, (2) analysis requirements test, and (3) hypothesis testing.

\section{RESULTS AND DISCUSSION}

Hypothesis test was done after testing the data analysis requirements namely the normality test and the homogeneity test. After the data were supposed to have met the requirements to be tested, then the hypothesis is tested by using the t test and the F test to determine the effect partially and simultaneously on the variables. 


\section{Hypothesis Test 1 (H1)}

Table 1.The results of the t-test analysis for variable (X1) on $\mathrm{Y}$

\section{Coefficients $^{\mathrm{a}}$}

\begin{tabular}{|r|r|r|r|r|r|}
\hline & \multicolumn{2}{|c|}{$\begin{array}{c}\text { Unstandardized } \\
\text { Coefficients }\end{array}$} & $\begin{array}{c}\text { Standardiz } \\
\text { ed } \\
\text { Coefficient } \\
\mathrm{s}\end{array}$ & \multicolumn{2}{|c|}{} \\
\cline { 2 - 6 } Model & \multicolumn{1}{|c|}{ B } & Std. Error & Beta & $\mathrm{t}$ & \multicolumn{1}{|c|}{ Sig. } \\
\hline $1 \quad$ (Constant) & 14.444 & 9.968 & & 1.449 & .151 \\
Principal & .560 & .102 & .480 & 5.485 & .000 \\
policy (X1) & & & & & \\
\hline
\end{tabular}

a. Dependent Variable: Education quality (Y)

Source : The data results based on SPSS version 22

Based on the results of the $t$ test, it is found that the significance value is 0.000 . Since the significant value (probability) is smaller than $0.05, \mathrm{H} 0$ is rejected. This means that $\mathrm{H}$ a is accepted. Thus the performance of the principal has the effect of $\mathrm{X} 1$ on $\mathrm{Y}$ which is equal to $0.000<0.05$. Moreover, the $\mathrm{t}$ value is $5.485>\mathrm{t}$ table 1.660 , so it can be concluded that $\mathrm{H}$ al is accepted. It means that there is a significant influence between $\mathrm{X} 1$ and $\mathrm{Y}$.

\section{Hypothesis Test 2 (H2)}

Table 2.The results of the t-test analysis for variables (X2) on Y

\section{Coefficients $^{\mathrm{a}}$}

\begin{tabular}{|c|r|r|r|r|r|}
\hline \multirow{2}{*}{ Model } & \multicolumn{2}{|c|}{$\begin{array}{c}\text { Unstandardized } \\
\text { Coefficients }\end{array}$} & \multicolumn{2}{|c|}{$\begin{array}{c}\text { Standardized } \\
\text { Coefficients }\end{array}$} & \multicolumn{2}{|c|}{} \\
\cline { 2 - 6 } & $\mathrm{B}$ & $\begin{array}{c}\text { Std. } \\
\text { Error }\end{array}$ & Beta & $\mathrm{t}$ & Sig. \\
\hline (Constant) & 14.444 & 9.968 & & 1.449 & .151 \\
Education financing (X2) & .258 & .096 & .236 & 2.696 & .008 \\
\hline
\end{tabular}

a. Dependent Variable: Education quality (Y)

Source : The data results based on SPSS version 22

Hypothesis Test 3 (H3)

Table 3. The results of Analisis by using f-test

ANOVA $^{b}$

\begin{tabular}{|r|r|r|r|r|r|}
\hline \multicolumn{1}{|c|}{ Model } & $\begin{array}{c}\text { Sum of } \\
\text { Squares }\end{array}$ & df & $\begin{array}{c}\text { Mean } \\
\text { Square }\end{array}$ & F & Sig. \\
\hline $1 \quad$ Regression & 7143.920 & 2 & 3571.960 & 29.436 & $.000^{a}$ \\
Residual & 11770.720 & 97 & 121.348 & & \\
Total & 18914.640 & 99 & & & \\
\hline
\end{tabular}

a. Predictors: (Constant), Education financing (X2), principal policy (X1)

b. Dependent Variable: Education financing (Y)

Based on the value above, it is shown that the significance value for the effect of $\mathrm{X} 1$ and $\mathrm{X} 2$ on $\mathrm{Y}$ is $0.000<0.005$ and the $\mathrm{F}$ value of 29.436> F table 2.70.
Thus, it can be concluded that Ha 3 is accepted, which means that there is a significant influence $\mathrm{X} 1$ and $\mathrm{X} 2$ on $\mathrm{Y}$. 
Before the research was under taken, the data requirements were tested first, namely the validity test and the reliability test. The data validity test was conducted by using the validation test consulted with the validators. The validators were the lecturers of Universitas PGRI Palembeng. The test was validated by using the analysis of SPSS program version 22 . The results of the analysis validation for the principal's policy variable were valid. In addition, the statement items can be tested further. The results of the researach in the validation analysis for the education financing variables show that all of them are valid. The statement items can be tested further. The results of the validation analysis for the education quality variables note that all of them were valid so that the statement items can be tested further. Then the prerequisite data test is continued to the reliability test. After calculating by using the SPSS version 22 program, it is revealed that the principal's policy variable obtained a value greater than the $r$ table. The education financing variable was greater than the $r$ table, and the education quality variable obtained a value bigger than the $r$ table so the conclusion can be taken that all research variables were stated reliable.

\section{CONCLUSION}

It can be inferred based on the findings that the principal policy has an influence on the quality of education. The results were proven by the $t$ test analysis. It shows that there is an effect of the principal policy on the quality of elementary school in Jejawi District. The results has answered the hypothesis 1 . Also, education financing has an effect on the quality of education which is based on the findings of the t test analysis. It shows that there is an effect of education funding on the quality of education in elementary schools in Jejawi District which has answered the second hypothesis. Principal Policy and Education Financing have a joint influence on the quality of education of the $\mathrm{F}$ test analysis. This shows that there is an effect of the principal policy and education financing on the quality of Elementary School in Jejawi District. The results have answered the hypothesis 3 .

\section{ACKNOWLEDGMENT}

The writers appreciate all families and friends who have given the supprts. The writers are also thankful to the rector of PGRI University of Palembang, (Direktur Pascasarjana, the chairman of management study of graduate program. Also, the writers are indepted to the supervisors who have guided and help to finish the paper. Thanks are also addressed to all friends in graduate program of Universitas PGRI Palembang and those who have given the assistance in accomplishing the writing process.

\section{REFERENCES}

[1] Undang-Undang Nomor 32 Tahun 2004 Tentang Pemerintahan Daerah.

[2] Hidayat. A, \&Machali. I (2012). Pengelolaan Pendidikan, Yogyakarta:Kaukaba.

[3] Wahjosumidjo (2010). Kepemimpinan Kepala Sekolah, Tinjauan Teoritik Dan Permasalahannya, Jakarta: Raja Grafindo Persada

[4] Mulyasa, E. (2016). Menjadi Kepala Sekolah Profesional. Bandung: Remaja Rosda karya

[5] Damayani, Titin., Arafat, Y. dan Eddy, S. (2020). Pengaruh Kepemimpinan Kepala Sekolah dan Motivasi Kerja terhadap Kinerja Guru. Journal of Innovation in Teaching and Instructional Media Vol. 1 No. 1, Page:46-57.

[6] Harapan, E. (2020) Pembiayaan Pendidikan, teori dan praktik menggali sumber pembiayaan pendidikan Nasional. Jurnal Manajemen, Kepemimpinan, dan Supervisi PendidikanVolume 1, No. 2, Juli-Desember 2016

[7] Robbin dan Coulter. (2003). Manajemen edisi kedelapan. Jakarta: PT Indeks.

[8] Alhusaini.A, Kristiawan.M, dan Eddy. S (2020). Pengaruh Motivasi Kerja dan Disiplin Kerja Terhadap Kinerja Guru. Jurnal Pendidikan Tembusai. Volume 4 Nomor 3 Tahun 2020. ISSN: 2614-3097

[9] Sihotang. A (2007). Manajemen Sumber Daya Manusia. Jakarta : PT. Pradnya.

[10] Purwanto (2014). Administrasi Dan Supervisi Pendidikan. Bandung: Remaja Rosda karya

[11] Sukmadinata, N. S. (2015). Metode Penelitian Pendidikan. Bandung: Remaja Rosda karya.

[12] Sugiyono. (2018). MetodePenelitianKuantitatif. Bandung: Alfabeta. 